KAIROS ELT JOURNAL, Vol. 1, No. 3, December 2017

Copyright $\odot 2017$, ISSN: 2580-4278

\title{
IMPROVING STUDENTS' VOCABULARY MASTERY BY USING PICTURES MEDIA TO THE SEVENTH GRADE STUDENTS OF SMP NEGERI 21 MEDAN
}

\author{
Merry Christina Turnip, Linus Rumapea, Anna Stasya Prima Sari \\ Catholic University of Saint Thomas
}

\begin{abstract}
This thesis discusses about the improving students' vocabulary mastery by using pictures media to the seventh grade students of SMP Negeri 21 Medan. This study applies pictures, one of media which can be used by the teacher to build students' mastery of vocabularies. To master the language, vocabulary is important element in learning process. This statement is supported by Thornbury. He said that without vocabulary nothing can be conveyed. This study is a field study in two cycles; each cycle consists of planning, action, observation, and reflection. In collecting data, I used qualitative and quantitative data. The qualitative data are observation sheet, and questionaire and field notes. The qualitative data were collected through observing the teaching learning process, holding the discussion with the teacher, and taking photographs of the teaching learning process. The quantitative data are pre-test and post-test to measure the students' vocabulary mastery by using pictures media. The instruments for collecting data were observations checklist, field notes, and photographs. This study concludes that the students' vocabulary mastery is improved by using pictures media. It can be seen from the means score of pre test is 65 , and post test is 78 . In additional, the implementation pictures media are successful to help the students memorize and understand new words easily.
\end{abstract}

Keywords: vocabulary mastery, pictures media

\section{INTRODUCTION}

Teaching vocabulary is very important. It is very important because without vocabulary students cannotspeak, write, and understand the meaning of a sentence or cannot understand what people say. Vocabulary is a fundamental component of second language proficiency; one of the primary goals of language learning is to know the meanings of the words.

Hornby in Choiriyah (2004:313) states , "Vocabulary is the total number of the words (with their meaning and with rules for combining them) making up the language". Vocabulary mastery is one of the components to master English. The students have the ability in understanding and using the meaning of the words. The students not only need to learn a lot of words, but to remember them. By mastering a number of vocabularies the studentsunderstood what hear and read, and they able to say what they want to speak and write.

Teaching English as a foreign language is not same as teaching English as second language. Teaching English as a foreign language means teaching the students in the target language in order to be able to use English for communication. However, environment did not help the students in learning the English language. The learners did not use English outside of the classroom. They just use English when they have an English class. Consequently, the learners did not have many opportunities to practice English in their daily activities. Learning and teaching English as a foreign language need the real situation to support the learners to use English naturally. Teacher should bring the real situation in the classroom by giving activities that support students to practice English. The teacher created media of teaching English based on the real situation that the students can apply and practice the language freely and naturally.

Based on observation toward to the seventh grade students of SMPNegeri 21 Medan, when the teacher was teachingEnglish, I found that thestudents seemed to be unenthusiastic, 
$60 \%$ of the students focused on their own activities and $40 \%$ of them gave their responses to the teacher's questions in learning English during the teaching learning process. The students have limited comprehension to recognize the meaning of each word uttered by their teacher of English. Moreover, the students were difficultto communicate in English. It made the students lazy to learn English. The students did not give attention when the teacher was explaining the material in the class. They just kept silent if the teacher asked them a question in English. After the class was over, I also interviewed three students, namely BM, SK, and MT. The students said that they often felt afraid of learning English because they did not have enough understanding of the meanings of the English words and afraid make a mistake.

I interviewed Ma'am H. Simbolon the teacher of English of to the seventh grade students of SMP 21Negeri Medan. She said that some of students still had less vocabulary mastery. The students became passivein the classroom, so they are not able to catch point of knowledge which was delivered by her. It was proven by theaverage their score about 50 65 which had not reached standard score of the Minimal Criterion Mastery (KriteriaKetuntasan Minimal (KKM) namely 70. So, to ge the Minimal Creation Mastery ( KKM) the teacher usually gave additional scores.

According to Larsen and Freeman in Donal(2012:78-79), “One of the effective teaching methods is by usingdirect method". The example of direct method is using pictures in teaching English. It is very useful because it will motivate students to know the new words. Besides that, the use of pictures media can help students to imagine the situation and things based on the pictures given. Teaching and learning vocabulary by using media created relaxing and motived atmosphere.

According to Muliana in Alfiyah (2014:308), "Media is one of the tools which can help teaching and learning process in the classroom easier".Media is a tool, method and technique that is used in order to make the teaching and learning process more effective between teachers and students. Media as an instrument can affect the condition of teaching learning process. Besides that, media is one way to make learning process more interesting, so that the studentsgave their attention and more focus on what the teacher teaches.There are many media that can be used for teaching vocabulary. Teacher should be creative in choosing media to teach the students in order to make the students are motivated to learn English especially in vocabulary mastery.

Picture is one of media which is relatively cheaper than the other media. It is alsoeasy to find.Using picture is suitable for teaching English, for it can stimulatestudents' imagination and creation in learning English. Moreover, pictures media can also improve motivation and make the students' learn vocabulary easily. Picture also supports the student ability to remember the words, meaning and the form of object.

Wright (1989:2) states,"Pictures are media that can be applied in teaching and learning English. The pictures motivated the students to get ideas, information and make the students more interested to study English".Indeed, it makes the aim of teaching and learning can be reached.

The students must improve their vocabulary mastery because theynot only learnt and found vocabulary in their English books but also in other books. There are also some English vocabularies that must be known by students. Sometimes the students are difficult to know ,understand, and memorize the vocabularies. Besides that, the students need to repeat vocabulary and work with a word or a phrase many times so that they can remember the new words which had been learned. Therefore, I applied pictures media to get goals in vocabulary teaching process.

From the statement above, it is summarized that pictures media is one of alternative and effective media that can be applied to improve the students' vocabulary mastery. Based on the 
KAIROS ELT JOURNAL, Vol. 1, No. 3, December 2017

Copyright $\odot 2017$, ISSN: 2580-4278

background of the study, I was conducted a research entitled "Improving Students Vocabulary Mastery by Using Pictures Media to the Seventh Grade Students of SMP Negeri 21 Medan. I hope that by using pictures media, the students more active and interested in teaching and learning English vocabulary.

\section{REVIEW OF LITERATURE}

\section{Vocabulary Mastery}

There are definitions of vocabulary given by experts. Vocabulary is one of the most important elements in a language. To speak the language we need to master vocabulary. No matter how well you learn grammar, how successfully the sound of a foreign language is mastered, without words to express a wider range of meanings, communication in the foreign language just cannot happen in any meaningful way.

Vocabulary is central to English language because without sufficient vocabulary students cannot understand the others or express their own ideas. Mastering English vocabulary in the process of teaching and learning English in Junior High School is very important. Mastering is a large numbers of vocabularies very important for foreign language learners.Without mastering it, foreign language learners will get some difficulties in developing the four skills.

According to Nunan (1991: 118), Vocabulary is an element in the acquisition of a second language. It means that vocabulary is one of the language components which have to be mastered by the students in learning a new language.

Vocabulary is the basic component of English. It means, students should learn vocabulary in order to be able in achieve the four language skills. In listening, listeners hear words; in speaking they produce words, in reading they have to understand word and in writing they use words to express their thought.Vocabulary mastery also plays an important part in English skillnamely, listening, speaking, reading, and writing skill, more vocabulary the students get more ability in language skills. Vocabulary is the knowledge of words and meaning of words.

According to Hatch\&Brown (1995:1)"The term vocabulary refers to a list or set of words for particular language or a list of words that individual speakers of language use ".Vocabulary is a fundamental component of second language proficiency; one of the primary goals of language of language learning is to know the meaning of the words.

Lewis and Hill (1990: 12) state, "Vocabulary mastery is important for the students. It is more than grammar for communication purpose, particularly in the early stage when students are motivated to learn the basic words. Without having proportional English vocabulary, students will get some difficulties in using English".Most of the students get much difficulties in mastering English vocabulary because of lack of motivation, and the pronunciation that make most of students are difficult to memorize English vocabulary especially in mastering English vocabulary. They should master vocabulary so they can understand and memorize English vocabulary well. Learning vocabulary is basic important element of language. To be good on it, the students can master and understand English Language especially to understand the text written in English.

\section{The Importance of Vocabulary}

Vocabulary is one element of the language that should be learnand taught. It will be hard to master the language without mastering or understanding a certain number of vocabularies. Before teaching other aspects of language, vocabulary is the first step to be taught.If we have a little vocabulary, a language learner will not be able to master the language 
skills. It shows that vocabulary mastery has important roles in communication. Wallace in Furqon (2013:71) mentions two main reasons about the importance of vocabulary.

There are:

1) language exist two main skills spoken, written, both of them need vocabulary to develop the existence itself, and

2) Vocabulary is needed for production in learning English as a foreign language rather than only needed for recognition it.

By having a lot of vocabularies, we can improve our English. As vocabulary buildings are very important in any language learning because it has a close correlation with intellectual mature of the learners but also the fact that it helps a great deal in improvement of four language skills of the students.

Thornbury (2002:13) states,"Without grammarvery little can be conveyed, without vocabulary nothing can be conveyed". We can say very little with grammar, but we can say almost anything with words. If we understand, the main words are sentence we can usually get a good idea of it is meaning. In addition, if we understand what a sentence means, we can gradually come to see how is grammar works. It means we can say anything with words.

\section{Types of Vocabulary}

Hatch \&Brown (1995:1) divides two kinds of vocabulary, namely receptive and productive vocabulary.

a. Receptive Vocabulary

Receptive vocabulary is words that the learners recognize and understand when they are use in context, but which cannot produce. It is vocabulary the learners recognize then they see or meet in reading text but do not use it in speaking and writing.

b. Productive Vocabulary

Productive vocabulary is the words that the learners understand, can pronouncecorrectly and use constructively in speaking and writing. It involves what is needed for receptive vocabulary plus the ability to speak or write at the appropriate time. Therefore, productive vocabulary can be addressed as active processbecause the learners can produce the words to express their thought.

\section{Teaching Vocabulary}

Words are essential to communication. Little children learn to speak in isolated words and then in chains of nouns and verbs. We expect students of a second language, however to control grammatical features of that language as well as its vocabulary. Regardless of the specific target language and the conditions of instructions, vocabulary is an important factor in all language teaching. The Students must continually be learning words as they learn structure and as they practice the sound system. Learning vocabulary of course must be according to level of age and ability of the students.

According to Nation (1990) there are parts of the course deliberately set aside for vocabulary development, namely:1)Focus on the most of useful vocabulary. First some words can be used in a wide variety of circumstances. Others have much more limited use. For example, the words "help"can be used to ask for help, to describe how people workwith others, to describe how knowledge, tools, and materials can make people work more easily. Teaching useful vocabulary before less useful vocabulary gives learners the best return for their learning effort. The most useful vocabulary is obviously needed by language learners whether they use the language in formal and informal situation. 2)Focus on the vocabulary in appropriate way. The first principle looksat what words to teach and learn. This principle looks at how they should be taught and learned. 3) Give attention to the high frequency words across the four 
strands of a course. High frequency vocabulary needs to occur in all four strands of a course. It should get deliberate attention through teaching and study and should be met and used in communicating messages in listening, speaking, reading, and writing. High frequency vocabulary should be fluently accessible for receptive and productive use. 4) Encourage learns to reflect and take responsibility for learning.

This is an important principle that lies behind choosing and learning, the learners need to realize they must be responsible for their own learning. Taking this responsibility requires knowledge of what to learn and the range of options for learning vocabulary, skill in choosing the best option and the ability to monitor and evaluate progress and evaluate progress with those options.

\section{Media}

According to Suyanto(2007:101), "Media are any means of communication which carry out the information between the source and the receiver". The media called instructional media if they are used to convey the messages in educational environment. Media is a physical tool which deliver massage and stimulate the students to study. So, media as an instrument can affect the condition and support the teaching learning process.

According to Suyanto (2007)there are 3 kinds of media such as:

1. Visual media is media that can be seen and touched, example: pictures, photo, real object, map, flashcard, and realia.

2. Audio media is media that contain record text to listen, example: radio and recorder, etc.

3. Audio visual media is that have sound and picture, example: TV, film, etc.

\section{Pictures}

Scrivener (1994) states, "Pictures can be drawn on the board or on posters". They have been used a starting point for mastering vocabulary. Wright (1989:2) states, "Pictures are media that can be applied in teaching and learning English. The pictures will motivate the students to get ideas, information and make the students more interested in studying English". Picture also supports the student ability to remember the words, meaning and the form of object. Nowadays, learning and teaching through pictures are very popular, most text books in English especially primary school up to senior high school are written with pictures. Considering this, it shows us that the pictures play important role to aid the students in learning English vocabulary. Moreover, picture is able to improve students' motivation. Indeed, it made the aim of teaching and learning can be reached.

For instance, when the teacher showed pictures, they can remember the similar scene, they sever seen and immediately recognize the components of the pictures. Their memory of the situation enables them to describe what it is even though there are no words given. It means that the picture has opened up the storage of words in their memory.

\section{The Advantages of Using Pictures}

Ransom in Donal (2012:82 ) also gives some advantages of pictures as follows: a) Picture provide settings for understanding and using new words, as they naturally spoken. b) Picture represent an important step in concept and vocabulary development c) Picture help broaden observation, opportunities and knowledge, resulting inenlarges and enriched vocabulary. All the advantages of pictures media above made the writer easier in improving students' vocabulary mastery. I was encouraged to use media to conduct this study using pictures media. 


\section{Teaching Procedure}

The teacher make or use a simple and easy pictures media that is suitable with students' ability and the teacher should select the words that answering pictures media.The procedure of using pictures media in vocabulary mastery teaching are as the following:1) the teacher showed to the students picture media related their topic, 2) the students identify what they see in the pictures, 3) the teacher asked them about the pictures media showed, 4) the students tri ed to explain what they had seen in the pictures , 5) the teacher explained about their topic by using pictures media and pronounce the words loudly, the students would repeat what the teacher has pronounced, 6 ) the teacher and students discussed about the difficult words, 7)the teacher gave exercise and asked the students to do it, 7) the teacher and the students discussed the answer exercise.

\section{RESEARCH METHOD}

In this research, Iapplied classroom action research method. Classroom action research begins with a question or questions about classroom experiences, issues, or challenges. It is a reflective process which helps teachers to explore and examine aspects of teaching and learning and to take action to change and improve the students' achievement in teaching and learning.Latief (2012:143) states, "Classroom Action Research is the media to increase the English teachers' quality in terms of performances of instruction as well as the students' achievement in learning English in a classroom effectively".

Metteal (2001:7) states, "Classroom Action Research (CAR) is a method of finding out what works best in your own classroom so that you can improve the students teaching and learning". The goal of Classroom Action Research (CAR) is to improve your own teaching in your own classroom.In this classroom action research, I collected the data by using qualitative and quantitative method. Wallace (1978: 38) state, "Qualitative data is to describe da ta which cannot be counted, or measured in objective way, while quantitative data is broadly used to describe what can be counted or measured".

\section{DATA ANALYSIS}

\section{The Data}

In this research, the data was conducted pre-test,posttest.The data of pre test and post test show the improvement of the students' score in vocabulary mastery. This research consists of two cycles and each cycle consistplanning, action, observation and reflection. I was done pre research. The purpose of doing pre research is to know how the media of the teacher in teaching learning process. So that, I can determine what are the steps of each cycle in this classroom action research.

Quantitative Data

The quantitative data was conducted vocabulary test. The tests were given in pre test in cycle I, post-test in cycle II, cycle $1 \mathrm{rank}$, cycle 2 rank. The purpose of this test is to measure the students' ability in mastering vocabulary.

Table 4.1 Pretest rank

\begin{tabular}{|l|l|l|}
\hline No & Categorize & Students' Score \\
\hline 1 & The Highest Score & 75 \\
\hline 2 & The Average Score & 65 \\
\hline
\end{tabular}


KAIROS ELT JOURNAL, Vol. 1, No. 3, December 2017

Copyright $\odot 2017$, ISSN: 2580-4278

\begin{tabular}{|l|l|l|}
\hline 3 & The lowest Score & 55 \\
\hline
\end{tabular}

Based on the result of pre- testshowed that the mean score is 65 .The highest score is 75 , and the lowest score is 55. It can be concluded that the students' understanding of vocabulary mastery was low.The result of pre test is to know the students' ability in vocabulary mastery before taught by using pictures media.

Table 4.2. Frequency Distribution for Students' Score

\begin{tabular}{|l|l|l|l|l|}
\hline No & Interval Score & Frequency & Categorize & Percentage \\
\hline 1 & $90-100$ & 0 & Very Good & $0 \%$ \\
\hline 2 & $80-89$ & 0 & Good & $0 \%$ \\
\hline 3 & $70-79$ & 22 & Fair & $55 \%$ \\
\hline 4 & $60-69$ & 12 & Poor & $30 \%$ \\
\hline 5 & $40-59$ & 6 & Very Poor & $15 \%$ \\
\hline
\end{tabular}

Based on the table above, it showed that before the teacher taught by using pictures media, there are $0(0 \%)$ students got good score, $22(55 \%)$ students got enough score, and12 $(30 \%)$ students got poor score, and $6(15 \%)$ students got very poor score. There are 22 students who passed Minimal Creation Score (KKM), and 18 students did not passed Minimal Creation Score (KKM).

Table 4.3. Cycle 1 rank

\begin{tabular}{|l|l|l|}
\hline No & Categorize & Students' Score \\
\hline 1 & The Highest Score & 80 \\
\hline 2 & The Average Score & 70 \\
\hline 3 & The lowest Score & 60 \\
\hline
\end{tabular}

Based on the result table 4.3, it showed that the mean score is 70. The highest score is 80 , and the lowest score is 60 . Itconcluded that the students' active, and interesting learnby using pictures media in cycle 1.

Table 4.4. Frequency for Distribution Students' Score

\begin{tabular}{|l|l|l|l|l|}
\hline No & Interval Score & Frequency & Categorize & Percentage \\
\hline 1 & $90-100$ & 0 & Very Good & $5 \%$ \\
\hline 2 & $80-89$ & 5 & Good & $12,5 \%$ \\
\hline 3 & $70-79$ & 25 & Fair & $62,5 \%$ \\
\hline 4 & $60-69$ & 10 & Poor & $25 \%$ \\
\hline 5 & $40-59$ & 0 & Very Poor & $0 \%$ \\
\hline
\end{tabular}

Based on the table, it showed that after the teacher taught by using pictures media, there are $5(12,5 \%)$ students got good score, $25(62,5 \%)$ students got fair score, and $10(25 \%)$ students got poor score, and $0(0 \%)$ students got very poor score.I concluded the students 
KAIROS ELT JOURNAL, Vol. 1, No. 3, December 2017

Copyright $\odot 2017$, ISSN: 2580-4278

interesting and easy to learn by using pictures media. There are 30 students got passed Minimal Creation Score (KKM).

Table 4.5. Cycle 2 rank

\begin{tabular}{|l|l|l|}
\hline No & Categorize & Students' Score \\
\hline 1 & The Highest Score & 90 \\
\hline 2 & The Average Score & 78 \\
\hline 3 & The lowest Score & 60 \\
\hline
\end{tabular}

Based on table 4.5, it showed after the teacher taught by using pictures media the average score in cycle 2 is 78 . The highest score is 90 , and the lowest score is 60 . It means that the students better than cycle 1 rank.

Table 4.6. Frequency Distribution for Students' Score

\begin{tabular}{|l|l|l|l|l|}
\hline No & Interval Score & Frequency & Categorize & Percentage \\
\hline 1 & $90-100$ & 3 & Very Good & $7,5 \%$ \\
\hline 2 & $80-89$ & 19 & Good & $47,5 \%$ \\
\hline 3 & $70-79$ & 15 & Fair & $37,5 \%$ \\
\hline 4 & $60-69$ & 3 & Poor & $7,5 \%$ \\
\hline 5 & $40-59$ & 0 & Very Poor & $0 \%$ \\
\hline
\end{tabular}

Based on the table, it showed that after the teacher taught by using pictures media, there are $7,5 \%$ students got good score, $19(47,5 \%)$ students got enough score, and $15(37,5 \%)$ students got fair score, $3(7,5 \%)$ students got bad score. It means that pictures media gave motivateto the students'to understand of vocabulary mastery than cycle 1 . There are 27 students got Minimal Creation Score (KKM), and 3 students did not passed Minimal Creation Score (KKM), namely 70.

Table 4.7. Post-test rank

\begin{tabular}{|l|l|l|}
\hline No & Categorize & Students' Score \\
\hline 1 & The Highest Score & 90 \\
\hline 2 & The Average Score & 78 \\
\hline 3 & The lowest Score & 65 \\
\hline
\end{tabular}

Based on table 4.7 post test showed that the average score in post-test is 78 , the highest score is 90 , and the lowest score is 65 . It was proven post test in cycle 2 better than pre test in cycle 1 to improve students' vocabulary mastery by using pictures media.

Table 4.8. Frequency Distribution for Students' Score

\begin{tabular}{|l|l|l|l|l|}
\hline No & Interval Score & Frequency & Categorize & Percentage \\
\hline 1 & $90-100$ & 1 & Very Good & $2,5 \%$ \\
\hline 2 & $80-89$ & 26 & Good & $65 \%$ \\
\hline 3 & $70-79$ & 5 & Fair & $12,5 \%$ \\
\hline
\end{tabular}


KAIROS ELT JOURNAL, Vol. 1, No. 3, December 2017

Copyright $\odot 2017$, ISSN: 2580-4278

\begin{tabular}{|l|l|l|l|l|}
\hline 4 & $60-69$ & 8 & Poor & $20 \%$ \\
\hline 5 & $40-59$ & 0 & Very Poor & $0 \%$ \\
\hline
\end{tabular}

Based on the table 4.8, it showed that after the teacher taught by using pictures media, there are $1(2,5 \%)$ student got score, $26(65 \%)$ students got good score,5(12,5\%) students got fair score, $8(20 \%)$ students got poor score, and $0(0 \%)$ students got very poor score. It means that pictures media was motivated the students to improve vocabulary mastery by using pictures media. There are 28students who passed Minimal Creation Score (KKM), and 12 students did not passed Minimal Creation Scores (KKM).

\section{The Qualitative Data}

Qualitative data was applied to describe the situation during teaching process. The qualitative data were gotten from field notes, observation sheet, and questionnaire. It described as follows:

\section{Field Notes}

I was conducted observation all activities in every meeting during conducting research. There are eight meeting was done. Four meetings in cycle 1 , and four meetings in cycle 2 . The first cycle gave pre test, and the eight meetings gave post -test. There are 20 mulltiple choice form. The second to the seventh meeting taecher gave homework or quiz. It described as follows:

First meeting (cycle 1)

The first meeting was conducted on Friday 06October 2016, started at 08.45to 10.10 o'clock am. I andcollaborator entered the classroom together. Beforestarted teaching and learning process, the teacher greeted the students, asked their condition. The teacher went sat in front of the class, while the collaborator sat in the back of the class. I didn't forget to check their attendance by asking question, "Who is absent today?" The students answered, "No body absent miss". They were completed 40 students. After that, the teacher gave pre -test,there are 20 multiple choices form. When students did the test, she walked around the class to check the students'condition as long as do pretest. They really surprised when gave a test for them and prohibited them. Some students were busy to do other activities, made noise and did not do the test seriously. When thefinished doing the pre test, I collected the test. Before the leaving classroom I lead the prayer and then left the classroom.

\section{Second Meeting (cycle 1)}

The first meeting was conducted on Friday, 07October 2016 started at 08.10 to 10.10 o'clock am. Before started teaching and learning process, the teacher greeted the students and condition of class.The teacher went sat in front of the class, while the collaborator sat in back of the class. I didn't forget to check their attendance by asking question, "Who is absent today?" The students answered, "No body absent miss". They were completed 40 students. The teacher lead pray.

The teacher explained about things in the classroom and our bag. When the teacher asked about the meaning of things in the classroom, most of them try to answer. The students answer "benda- bendadikelasyamiss". The teacher asked the students to mention in English language. Some students could give some answers such as: book, pen, pencil, white board, table. The teacher showed pictures about their topic. The teacher said "who knows pronounce this words, some students try to pronounce and repeat togetherafter the teacher. In the end of the lesson,I review their topic and gave homework to them, then the teacher asked the students 
"any question so far? The students answered, "No miss". Then, the teacher said "Okay my dear students, let's sing together" then sang a song together around two times, and the teacher said "See you later, See you miss.

\section{Third meeting}

The second meeting in cycle one was conducted on Thursday, 13October 2016 started at 08.45 to 10.10 o'clock a.m. I and my collaborator entered the classroom together. The teacher greeted the students, asked their condition. I didn't forget to check their attendance by asking question, "Who is absent today?" The students answered, "Ibnu miss". They were 39 students, one of students was sick. The teacher said some students lead pray. This activity same as first meeting the teacher showed pictures about their topic. Before starting the new material or new topic the teacher gave some questions to the students about their topic last week, teacher took two students in front of the class to explain their topic last week, and then checked together.

Next, I said the students to make group. There were 5 groups, consist 8 students and asked them to chose the leader in their group, The students doing exercises, and gave rewards who won. When I took two groups in front of the class to explain, the students became noisy when they answered the question. I explained to them about things in living room. All of them could give some answers such as: sofa, fan, cupboard, carpet, etc. In teaching learning activities in this cycle could run well. The students were interested and seriously when the lesson was presented.Finally, the teacher gave homework, then the teacher asked the students "any question so far? The students answered, "No miss". One of students lead the prayer and the teacher said see you.

\section{Fourth meeting}

Fourth meeting was conducted on Friday, 14October 2016 started at 08.45 to 10.10 o'clock a.m. I and my collaborator entered the classroom together. Before continuing teaching and learning process, I greeted the students, asked their condition, and check their attendance by asking question, "Who is absent today?" The students answered, "No body absent miss", we are

40 students. Then, we sang a song together and I lead the prayer. Fourth meeting, I showed the pictures related their topic. After I explain their topic, I pronounce loudly the words and the students repeat. The students seemed more enthusiastic to response teachers' instruction and most of them wants to tries to make to speak English language in the classroom. After finished, the teacher asked to us, who knows our topic today? Some of students try to answer "menghitung benda-benda"teacher said"that's right". The teacher told the students to answer in English. Erika said “counts things miss" teacher said "that's right and give a close". I checked the students understanding by giving some question about their topic, sometimes pointed of the students to answer the questions, the students were able answer her questions. Then, after teaching learning process finished, I gave homework, then the teacher asked the students "any question so far? The students answered, "No miss". Then, the teacher closed the class and said see you later.

\section{Fifth meeting (cycle 2)}

Fifth meetings second cycle was conducted on Friday, 20 October 2016 started at 08.45 to

10.10 o'clock a.m. I and my collaborator entered the classroom together. The teacher greeted the students, checked condition of class, and check their attendance by asking question, "Who is absent today?" The students answered, "No body absent miss". They were completed 40 students. Then, we sang a song together and prayer. Before continuing, I asked the students 
about the material before," Did you remember about our material in the last meeting?", and some students answered, "yes miss".I just gave a little explanation which had not been understood by the students until they understood well.

The topic in second cycle was Parts of body. The teaching learning processes same as in the first cycle, the teacher reviewed last topic. The vocabulary presented by using pictures media in the classroom. I asked "who knows parts of body? I took 3 students, but only one students answer, she said "hand, eyes, hair, elbow, feet, ear, etc. I said "give a close", The teacher said, "Mention parts of body, please!" They were still confused. She repeated the question in Indonesian. She said, sebutkan bagian-bagian tubuh, gunawan answered, "pinggul miss". The teacher said, "Good "it is hip". I explain their topic by using pictures, all of students listened and paid attention to the performances seriously. I pronounce the words and the students repeat loudlyI always corrected if they did not understand or made some mistakes in their pronunce. The teacher also guided them when they got difficulties in practicing the topic. To improve their vocabulary they must be memorize of words and I asked them try to write down the vocabulary mastery on white board. Finally, I reviewed their topic and homework, then I asked "any question so far? The students answered, "No miss". Then, the teacher closed the class and she said see you later.

\section{Sixthmeeting}

Sixth meeting was conducted on Thursday, 21October 2106 started at 08.10 to 10.10 o'clock a.m. I and collaborator entered the classroom together. I greeted the students, asked their condition, and check their attendance by asking question, "Who is absent today?" The students answered, "No body absent miss". They were completed 40 students. Then, we sang a song together and lead the prayer.

I explained about "describing people and Animal. I showed to the students pictures related their topic. Before continuing their lesson, the teacher asked the students " who knows their topic tomorrow". Most of them to answer, I wrote the example of describing people, then the students wrote in their book, after that I explained by using pictures media. I read and pronounce difficult word. I said some of the students in front of class, and then we were described together. I also guided them when they get difficulties in the material. The teacher said to the students make 5 groups, consist 8 students. I gave exercises and reward which groups the winner. Finally, I gave homework about describe their friends, the teacher asked the students "Any question so far? The students answered, "No miss". Then, I said see you and left the class.

\section{Seventh meeting}

Seventh meeting in cycle two was conducted on Thursday, 23October 2106 started at 08.45 t0 10.10 o'clock a.m. I and my collaborator entered the classroom together. I greeted the students, asked their condition, and check their attendance by asking question, "Who is absent today?" The students answered, "No body absent miss". They were completed 39 students, one of them was sick. Then, we were sang a song together and prayer. I showed to the students pictures about their topic, some of the students did not understand and said "itu gambar-gambar apa miss dan kita belajar apa miss". Before I explained their topic and I asked who knows our topic today? One of them answered, "short notice ya miss" and the other students answered," peringatanya miss? And then I explained their topic clearly and pronounce the words. I took 2 students to write down the example of short notice, but all of them try to write down on the white board. I also guided them when they got difficulties in the material. I asked the students make 5 groups consist 8 students and gave exercises about their topic. Finally, the teacher 
KAIROS ELT JOURNAL, Vol. 1, No. 3, December 2017

Copyright $\odot 2017$, ISSN: 2580-4278

reviewed their topic and gave homework, then the teacher asked the students "Any question so far? The students answered, "No miss". Then, the teacher closed the class and said see you.

\section{Eight meeting}

Fourth meeting was conducted on Friday, 24October, 2016 started at 08.45 to 10.10 o'clock a.m. I and my collaborator entered the classroom together. I greeted the students and condition of class. I didn't forget to check their attendance by asking question, "Who is absent today?" The students answered, "No body absent miss". They are 40 students. Before I gave post-test, I said that this is the last meeting and gave post test and there are 20 multiple choices form. The post test was done around 40 minutes. After the students finished, we sang a song and the teacher lead the prayer.

\section{The Observation Sheet}

The observation sheet used to observe me all activities during research in cycle 1 and cycle

2, I had managed the classroom well and present their topic well during research.It was seen from the condition of the students who give full attention and participation during the classroom activities, they felt enjoy and motivated to memorize and learning English, and also It seen from their enthusiastic and more interested in the lesson during the teaching learning process and the increase of their understanding and memorizing from their scores after the students teaching and learning vocabulary mastery by using pictures media,it was proven the students gave positive responses in all activities. (It can be seen in the appendix).

\section{Research Findings}

Research findings were taken from the quantitative and qualitative data. the quantitative data were taken from the students' score in pretest and post-test score. The result of the posttest score was higher than pretest score. We could answer the first problem of the research that the vocabulary mastery of the students improved after have been taught by using pictures media. The qualitative data were taken from the field notes and observation sheet, and questionnaire which were shown in appendix. We could see that the students felt excited in learning vocabulary using pictures media .

It also could be seen from the students' score which improved from $0 \%$ to $90 \%$. It could be concluded that the students' score increased because the students enjoyed and felt interested in learning vocabulary mastery by using pictures media.

\section{Discussion}

In this section, I would like to analyze all data. In the first meeting, the students look afraid and they are shy. In first cycle by using pictures media, the students are more enthusiastic and comfort in the teaching and learning process. This media used to help and encourage many learners to sustain their interest. This media sometimes works in groups and pointed of them the leader their groups. The students have spirit in the first cycle. Several data took from the field notes. In the first cycle, the researcher concluded the students enjoy and interest with the pictures media. The mean score of pre-test is 65 and the post-test is 78 .

Then, the second cycle was conducted to the students by revising the teaching technique and some aspects which occurred in the first cycle in order to improve the students' vocabulary mastery. In the vocabulary teaching learning process, the English teacher asked the students to bring their own dictionary which could help them to find the meaning of the difficult words found in the text. Next, in the activity of vocabulary exercise, the teacher asked the students to work in group in order to share the knowledge with their groups in answering the questions. 
This strategy allowed the students to practice either individually or in group in formulating their ideas and provided an opportunity to the students to share their knowledge with others, the students are more spirit and relax because they have known about pictures media. When the pictures media applied happy, enjoy, active and more relax. They have spirit to go in front of the class. Many students become active to speak up and they have brave to ask about their topic namely (Erika,Ibnu, Erika,Verol, Krisna, Vani). I concluded that teaching and learning by using pictures media can improve the students' vocabulary mastery by using pictures media.

\section{CONCLUSIONS}

I conclude that teaching vocabulary mastery using pictures media is more effective . Based on the results of vocabulary test after the actions are given in two cycles, it could be concluded that the teaching of vocabulary by using picture media could improve the students' vocabulary mastery as well as their active participation in the classroom. It can be seen from the students' score of post test that is higher than the score of students' to understand the difficult words easily by guessing the meaning, the use of pictures media made the vocabulary learning becomes enjoyable and interesting because they had discovered the meaning of difficult words by looking the pictures media of them in pictures without asking another person or looking them up in the dictionary.

Furthermore, pictures media also makes the students more creative, and learning becomes enjoyable and interesting because they can make their students understood about the vocabulary.

\section{BIBLIOGRAPHY}

Alfiyah, Siti. Improving the Ability To Write Descriptive Text Through Pictures as Instructional Media. “Jurnal Penelitian, Pendidikan, dan Pembelajaran.” 2014.3(13), 304-305.

Burns. Doing Action Research in English Language Teaching: A Guide for Practionery.Sedney: Macquarie. 2010.

Best \& Khan.The Important of Vocabulary Mastery in Language Learning and How to be Taught. "International Journal of Teaching and Education”. 2002. 3(3), 28-35.

Choiriyah, Siti. The Use of Electronic Picture Books to Improve the Vocabulary Mastery of Seventh Grade Students of SMP. "JurnalPenelitian, Pendidikan, dan Pembelajaran”. 2004. 3 (13), 312-313.

Donal, Andri. Improving the Esp Students' Vocabulary by Using Pictures inAgribusiness Study Program of the University of Pasir Pengaraian. "Jurnal Pendidikan dan Pembelajaran”.2012 .1(1), 308-309.

Furqon, Fajar. Correlation Between Students' Vocabulary Mastery and Their Reading Comprehension. "Jurnal of English and Education". 2013. 1 (1), 71-72.

Hatch, \& Brown. Vocabulary, Semantics, and Language Education. Cambridge:Cambridge University Press.1995.

Latief,Adnan. Research Method on Language Learning: An Introduction. Malang: UM Press. 
KAIROS ELT JOURNAL, Vol. 1, No. 3, December 2017

Copyright $\odot 2017$, ISSN: 2580-4278

2012.

Lewis \& Hill . Practical Techniques for Language Teaching. London: Commercial Colour Press, Plc. 1990.

Metteal, Gwynn. The what, why and how of classroom action research. "Jurnal of Scholarship of Teaching and Learning”. (JoSoTL), 2 (1) 6-13. 2001.

Nation. I. S. P. Teaching and Learning Language. New York: New Burry House.1990.

Nunan, David.Practical English Language Teaching Young Learners. New York:Mc-Graw Hill ESL/ELT.2006.

Scrivener, Jim. Learning Teaching: A Guide for English Language Teacher: Macmilan. 2nd edition.1994.

Suyanto, Kasihani. English For Young Learners. Jakarta: Bumi Aksara. 2007.

Thornbury, Scott. 2002. How to teach Vocabulary. Malaysia: Pearson Education Limited.

Wallace, Michael. Action Research for Learning Teacher. Cambridge: Cambridge University Press.1978.

Wright, Andrew. Picture for Language Learning.Cambridge: Cambridge University Press.1989. 